the reactions between hydrogen peroxide and aldehydes in water.

C. A. Bunton

E. S. Halberstadt

Sir W. Ramsay and R. Forster

Laboratories,

University College London.

A. J. EvereTt

G. J. MinkofF

Chemical Technology Department,

Imperial College, London.

Sept. 30.

${ }^{1}$ Lapworth, J. Chem. Soc., 995 (1903); 120 (1904),

${ }^{2}$ Ghijsen, Dissertation, Delft (1942). Reiche, "Alkylperoxide und Ozonide" (Leipzig, 1931).

\section{Reaction between Manganous lon and Manganese Dioxide}

THE decrease of manganous ion concentration which occurs when a manganous salt is shaken with man. ganese dioxide has been known for a long time. Being most marked with freshly precipitated oxides, it is not surprising it should first have been considered an adsorption. For some time this observation has found practical application in the removal of soluble manganese in water supplies ${ }^{1}$, while recently it has been shown of significance in the chemistry of the dry cell depolarizer ${ }^{2}$, and also in the oxidationreduction cycle of manganese in the soil ${ }^{3,4}$.

In all instances the primary reaction is probably

$$
\mathrm{MnO}_{2}+\mathrm{Mn}^{++}+4 \mathrm{H}^{+}=2 \mathrm{Mn}^{+++}+2 \mathrm{H}_{2} \mathrm{O} \text {. }
$$

Except in the presence of concentrated acid, the equilibrium is such that the amount of $\mathrm{Mn}^{+++}$is very small. In the presence of pyrophosphoric acid, which forms a stable complex anion with trivalent manganese ${ }^{5}$, the reaction may proceed far to the right ${ }^{4}$. In the absence of complex-forming substances and in neutral and slightly alkaline solutions, a new solid phase appears, the reaction again proceeding to the right. One solid phase which has been observed at $p H$ values as low as 4.5 has been identified as manganite ${ }^{2}$. Its formation may be shown by rewriting the above equation so as to assume hydrolysis of the manganic ion, thus

$$
\mathrm{MnO}_{2}+\mathrm{Mn}^{++}+2 \mathrm{H}_{2} \mathrm{O}=2 \mathrm{MnOOH}+2 \mathrm{H}^{+} \text {. }
$$

Dion and $\mathrm{Mann}^{3}$ state the reaction proceeds only in the reverse direction. This is contrary to the above findings ${ }^{2}$ and to our own. In seeking a cause for potential drift with a manganese dioxide electrode? ${ }^{\text {? }}$, we have found that some such reaction proceeds even when the dioxide has the dense heat-stable pyrolusite structure; that it leads to the production of a lower oxide even at $p \mathrm{H}$ values as low as 1 ; and that this oxide has a structure not previously described.

Half-gram portions of dioxide obtained by heating pure manganous nitrate were allowed to stand for two days at room temperature with $50 \mathrm{ml}$. of the solutions shown in the accompanying table. The solid residues after washing and drying at room temperature in vacuo were examined by one of us (J. M. C.) by both the X-ray and electron diffraction methods. In each instance the $\mathrm{X}$-ray powder pattern showed only the lines of pyrolusite. However, the electron diffraction pattern from the sample treated with hydrochloric acid and manganous chloride had rings distinctly different from those of pyrolusite. The other treated samples gave a pyrolusite pattern, but in addition showed weakly the stronger rings of

\begin{tabular}{|l|c|c|}
\hline \multicolumn{1}{|c|}{ Reactants } & $\begin{array}{c}\text { X-ray diffraction } \\
\text { pattern }\end{array}$ & $\begin{array}{c}\text { Electron diffraction } \\
\text { pattern }\end{array}$ \\
\hline $\begin{array}{l}\text { Original } \mathrm{MnO}_{2} \\
\mathrm{MnO}_{2}, \mathrm{MnCl}_{2} 0 \cdot 1 M,\end{array}$ & $\begin{array}{c}\text { pyrolusite } \\
\text { pyrolusite } \\
\mathrm{HCl}_{0} \cdot 1 \mathrm{M}\end{array}$ & $\begin{array}{l}\text { pyrolusite } \\
\text { pyrolusite and new } \\
\text { oxide (strong) } \\
\text { pyrolusite and new } \\
\text { oxide (weak) } \\
\text { pyrolusite and new } \\
\text { oxide (weak) }\end{array}$ \\
$\begin{array}{l}\mathrm{MnO}_{2}, \mathrm{HCl}_{0} \cdot 1 \mathrm{Mn}\left(\mathrm{ClO}_{4}\right)_{3} 0 \cdot 1 M, \\
\mathrm{MClO}_{4} 0 \cdot 1 M\end{array}$ & pyrolusite \\
\hline
\end{tabular}

the new pattern. When manganese dioxide is dissolved in concentrated hydrochloric acid and the manganese tetrachloride hydrolysed, this new pattern is not obtained, but rather the pattern of $\gamma \mathrm{MnO}_{2}$ or of pyrolusite ${ }^{6}$.

The rings of the new pattern given by the sample treated with hydrochloric acid and manganous chloride show arcing when the specimen is tilted, most of the arcs lying along one diameter. This indicates that the substance is in the form of thin flakes, of the order of $100 \mathrm{~A}$. or less in thickness, lying flat on the supporting film of collodion. It seems probable that these flakes were formed by the breaking-off of an altered surface layer from the particles during the process of grinding the sample under secondary butyl alcohol. Lattice spacings and ring intensities are given below.

$\begin{array}{clcl}D & \text { Int. } & D & \text { Int. } \\ 5 \cdot 1 & \text { W } & 1 \cdot 74 & \text { M } \\ 4 \cdot 39 & \text { S } & 1 \cdot 62 & \text { M } \\ 4 \cdot 12 & \text { S } & 1 \cdot 58 & \text { MW } \\ 3 \cdot 34 & \text { W } & 1 \cdot 50 & \text { W } \\ 2 \cdot 46 & \text { S } & 1 \cdot 30 & \text { W } \\ 2 \cdot 35 & \text { M } & 1 \cdot 27 & \text { MW } \\ 2 \cdot 06 & \text { MW } & & \end{array}$

This pattern is similar to that of goethite, $\alpha \mathrm{FeOOH}$, and there is good agreement between the observed spacings and those calculated for an orthorhombic cell with dimensions $a=4 \cdot 42, b=10 \cdot 4, c=2 \cdot 83 \mathrm{~A}$., which are close to the dimensions of the goethite cell. However, interpreted on this basis, some reflexions are present which are not permitted by the space group of goethite, and some reflexions given by goethite are absent. Hence the substance cannot be considered as truly isomorphous with goethite. The data are not sufficient to allow a more definite determination of structure. Recently Gruner ${ }^{8}$ has briefly described a new mineral (groutite) found in Minnesota which has the cell dimensions $a=4 \cdot 56$, $b=10 \cdot 70, c=2.85 \mathrm{~A}$. It is considered, however, that these dimensions differ significantly from those of the oxide described here. No manganese analogue of goethite is reported by Dana, who lists the groups :

$$
\begin{aligned}
& \text { goethite }(\alpha \mathrm{FeOOH}), \quad \text { diaspore }(\alpha \mathrm{AlOOH}) \text {, } \\
& \text { lepidocrocite }(\gamma \mathrm{FeOOH}) \text {, boehmite }(\gamma \mathrm{AlOOH}) \text {, }
\end{aligned}
$$

\section{J. M. COWLEy Allian WalkLey}

Division of Industrial Chemistry,

Council for Scientific and Industrial Research, Box 4331, G.P.O., Melbourne.

$$
\text { Aug. } 15 .
$$

1 Tillmans, J., Hirsch, P., and Häffner, F., Das Gas und Wasserfach., 70, 26 (1927).

McMurdie, H. F., Craig, D. N., and Vinal, G. W., Trans. Electrochem. Soc. (Preprint), 90, 31 (1946).

'Dion, H. G., and Mann, P. J. G., J. Agric. Sci., 36, 239 (1946)

- Heintze, S. G., and Mann, P. J. G., Nature, 158, 791 (1946).

${ }^{5}$ Kolthoff, I. M., and Watters, J. I., Indust. Eng. Chem. Anal. Ed., 15, 8 (1943).

- Cole, W. F., Wadsley, A. D., and Walkley, A., Trans. Electrochem. Soc. (Preprint), 92, 2 (1947).

7 Wadsley, A. D., and Walkley, A., unpublished work (1947).

- Gruner, J. W., Amer. Min., 30, 169 (1945). 